\title{
MODEL ANALYZING FOR REUSING GOLD WIRE CAPILLARY IN THE GOLD WIRE BONDING PROCESS
}

\author{
ChATPON Phimpha *and Sombat SindhuchaO \\ Department of Industrial Engineering, Faculty of Engineering, \\ Ubon Ratchathani University, \\ Ubon Ratchathani 34190, Thailand \\ *Corresponding author: Perpetually09@gmail.com.
}

(Received: $3^{\text {rd }}$ December 2020; Accepted: $4^{\text {th }}$ February 2021; Published on-line: $4^{\text {th }}$ July 2021)

\begin{abstract}
Manufacturing process improvement is necessary for manufacturers to gain business advantages. Re-using or increasing the useful lives of machine parts is considered to be a process of performance improvement. To re-use parts, the manufacturers must know the effects of the factors related to workpieces' qualities to prevent defects. This research study aims at presenting the results of analysing the effects of the factors and mathematical models for bond shear strength when reusing gold wire bonding capillary in the gold wire bonding process of integrated circuit (IC) products using design experiment. The operation factors in the reference experiment, including bond force, bond time, USG current, EFO current and EFO gap, are investigated. The Fractional Factorial Design was used to determine five factors that affect the bond shear strength. The analysis of the results show that the bond force is a significant factor where increasing bond force factors leads to increasing bond shear strength. In the end, a Regression model of bond shear strength is obtained to show the result between the bond shear strength and effect of factors.
\end{abstract}

ABSTRAK: Proses pembaharuan pengilangan adalah penting untuk para pengilang bagi memperoleh keuntungan bisnes. Guna-semula atau menambah jangka hayat pada bahagian-bahagian tertentu pada mesin adalah dianggar sebahagian proses penambahbaikan prestasi mesin. Bagi mengguna semula bahagian-bahagian ini, pengilang mesti mengetahui akibat sesuatu faktor berkaitan kualiti bahan bagi mengelak kecacatan. Kajian ini bertujuan menyampaikan dapatan kajian melalui kesan faktor dan model matematik pada kekuatan ricihan ikatan apabila mengguna semula wayar emas melalui proses kapilari ikatan wayar emas pada produk litar bersepadu melalui rekaan eksperimen. Faktor operasi melalui rujukan eksperimen dari daya ikatan, masa ikatan, arus USG, arus EFO dan jarak EFO dikaji. Rekaan Faktorial Pecahan digunakan bagi mendapatkan lima faktor yang mempengaruhi kekuatan ricihan ikatan. Dapatan kajian menunjukkan daya ikatan merupakan faktor penting di mana, pertambahan faktor daya ikatan menguatkan ricihan ikatan. Akhirnya, model Regression kekuatan ricihan ikatan diperoleh bagi menjelaskan dapatan kajian antara kekuatan ricihan ikatan dan kesan faktor.

KEYWORDS: reusing capillary; gold wire bonding; bond shear; design of experiment

\section{INTRODUCTION}

Improving the production process to increase efficiency in the working process is an essential part of business. Factories are required to understand and develop their production processes to produce products or services that can meet customer needs and enhance business competitiveness with other factories producing the same product $[1,2]$. 
Machine parts that are expired from the manufacturing process are used. The parts are studied, and the effects of the factors are identified in order to re-use the parts or to increase the parts' useful lives. This is considered a strategy for reducing manufacturing costs and improving processes for business competitiveness. To re-use expired parts, the parts must be carefully considered, and the effects of the process factors must be identified in order to prevent defects [3].

Most studies focus on the factors of the best practices for new parts. However, this study aims at studying the effects of the process factors for expired parts. In order to make the manufacturers understand the effects of each factor of the qualities of the work pieces to efficiently use the parts without affecting the work pieces.

The gold wire bonding process is a process of integrated circuit (IC) products, which are the main parts in electronic devices such as mobile phones, televisions, etc., The IC packaging product consists of two main processes, namely, Front of Line (FOL) production, which consists of five sub processes, and End of Line (EOL) [4], which consists of four sub processes. The most important process of IC Packaging production is the gold wire bonding process in the FOL because it connects the main circuit of IC packaging using small gold wire [5,6]. In this process, high-precision machining and a large number of adjustment factors are required to process [7,8]. A machine part that is called a gold wire bonding capillary is an important part of the gold wire bonding process because this part presses on work pieces being wired. The gold wire bonding capillary is a small tube for bonding gold wires through the mentioned tube. By checking the manufacturing process, it was found that the gold wire bonding capillary can manufacture 150,000 work pieces. Then, the gold wire bonding capillary must be changed. Accordingly, this study emphasizes studying the effects of the quality factors of work pieces if the parts are expired in order to provide data for manufacturers who want to improve the efficiency of their processes by re-using parts and to help them know the data and relationships of the factors for manufacturing work pieces according to requirements [3].

Statistical methods are used to find the effect of factors to adjust the parameters of the gold wire bonding process to maximize bond shear strength. An experimental approach that defines parameters in a process is the design of experiment method [9]. Each of the researched studies demonstrated the application of experimental methods, showing various factors that affected the gold wire bonding process, including showing results of different research. The research work showed that an increase in bonding temperature affected the shear strength of gold bonding. The one-factor experiments were not suitable for the study of most factors in the same experiment [10]. The study also found research related to the use of analysis of variance (ANOVA) to analyse factors that affect the strength of wire bonding. ANOVA is an experiment that can be studied using multiple factors. However, the large number of factors are limitations to the number of the experiments [11]. According to relevant research reviews, the suitable method for determining the optimum conditions of the gold wire bonding process was factorial design (FD) [12]. A full factorial consists of all possible combinations of levels for all factors. The total number of experiments for studying are included in [13]. Consider the factors in which five factors were researched with two levels of factors by factorial, the design of a full factorial experiment should involve a total of 32 experiments. The Fractional Factorial Design (FFD) is one type of factorial experiment. It is an experiment that uses half the number of experiments from the design of a full number of factorial experiments. The objective of this research was to use fractional factorial experiment to determine the effect of 
parameters and show the regression model that is used for bond shear strength in the gold wire bonding process of IC packaging process.

\section{MATERIALS AND METHODOLOGY}

The process of bonding gold wire is summarized as follows: gold wire bonding starts with an electric current through a device called an EFO wand, which is responsible for distributing electricity to heat the gold wire in the capillary to form a spherical shape. The molten gold wire is then pressed onto the circuit pad, where the first connection is a spherical shape called the first bond, as shown in Figure 1(a). The machine then raises the gold wire and drags the gold wire to connect it to the second connection at the lead frame. The lead frame is the point used to connect the circuit of the IC packaging with the integrated circuits of various devices. At the second point of circuit connection, the gold wire is touched onto the lead frame and pressed to break the gold wire, producing a flat shape. This point connection is called the second bond, as shown in Fig. 1(b). The quality of the gold wire bonding is checked by bond shear strength. The bond shear test uses a machine to push the first bond area with a constant straight force. This process continues until the connected gold wire is damaged and the maximum strength obtained from the test is recorded. Figure 2(a) shows the picture of the product before the bond shear test. Figure 2(b) shows the picture of the product after the bond shear test, where the bonded gold wire was broken by the bond shear test as denoted by the red circle.

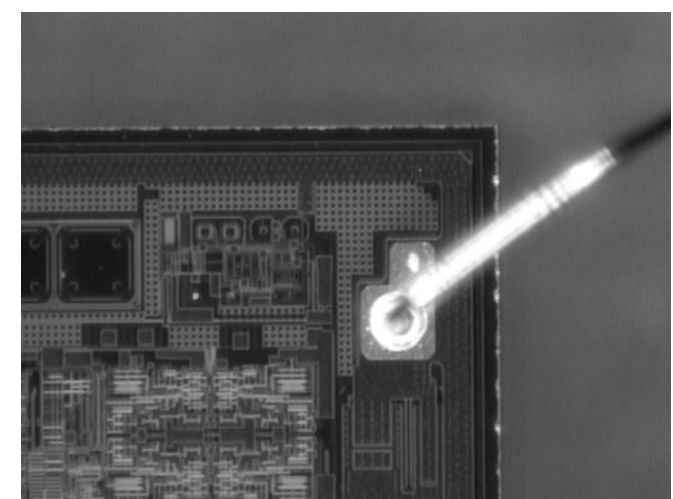

(a)

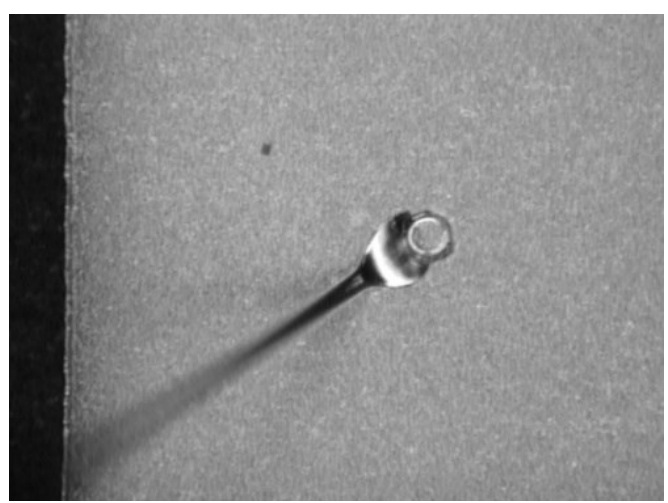

(b)

Fig. 1: (a) Appearance of the first bond, (b) appearance of the second bond.

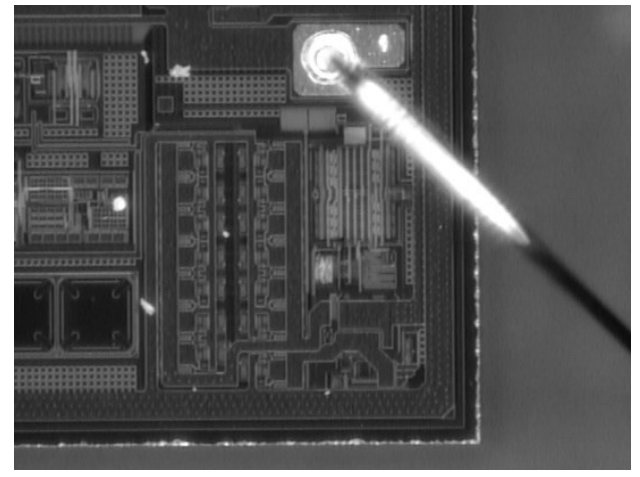

(a)

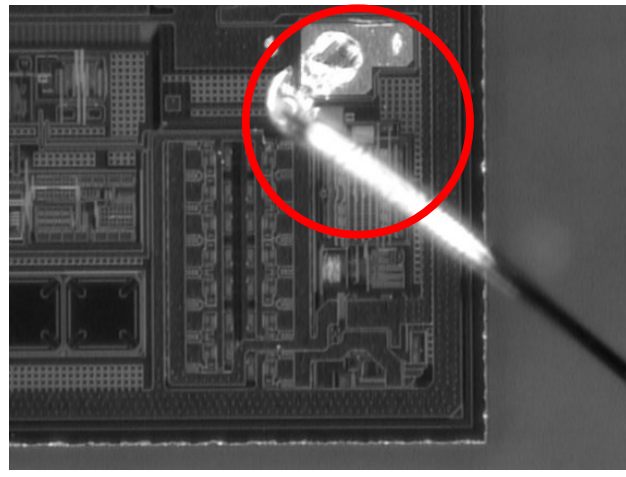

(b)

Fig. 2: (a)The first bond before the bond shear test, (b) the first bond after the bond shear test. 


\subsection{Machine and Materials}

In the experiments, the gold wire bonding capillary that is expired after manufacturing 150,000 work pieces is studied in order to investigate the effects of the factors of the shear forces in the gold wires. The reused capillary is shown in Fig. 3. The machines and materials used in this research include the gold wire bonding machine Model Kns IConn PLUS as shown in Fig. 4(a) and a gold wire size of 1.3 mils to connect the circuit. The 4000 series Multipurpose Bond tester machine was used for the quality control by recording the maximum shear strength, as shown in Fig. 4(b). In the experiments, the gold wire bonding capillary that is expired after manufacturing 150,000 work pieces is studied in order to investigate the effects of the factors of the shear forces in the gold wires.

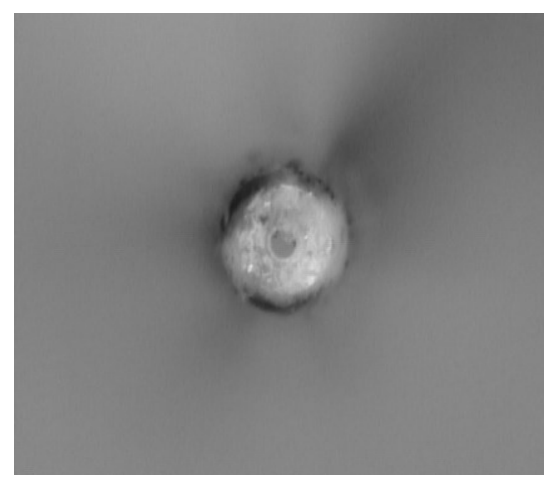

(a)

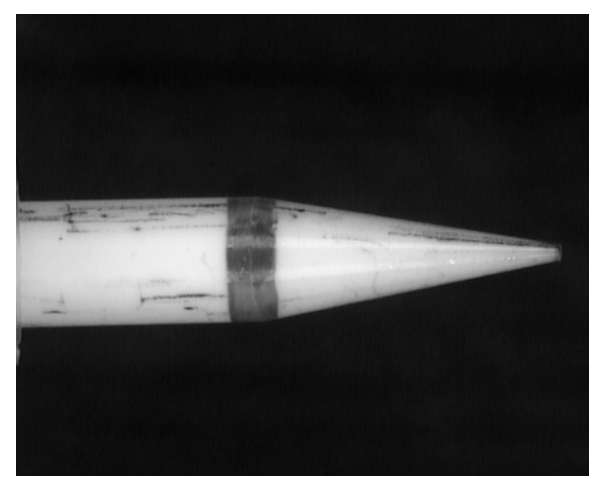

(b)

Fig. 3: (a) Front view of reused capillary, (b) side view of reused capillary.

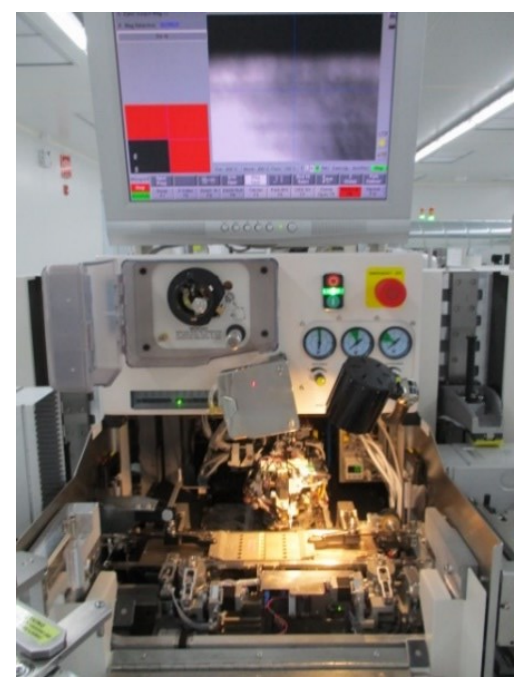

(a)

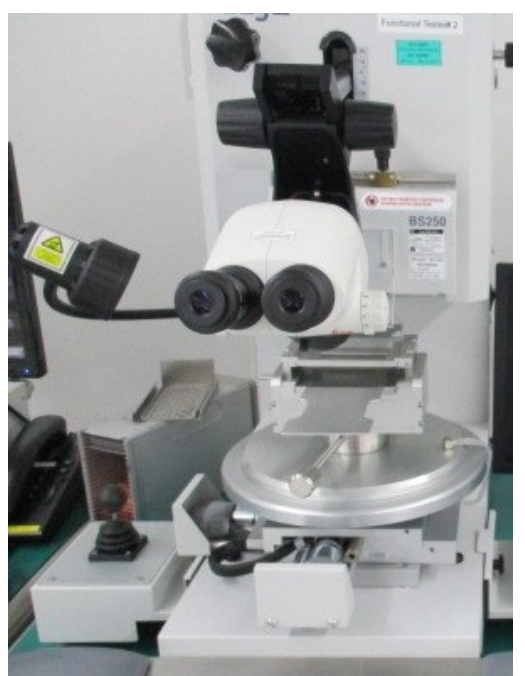

(b)

Fig. 4: (a) Wire bonding machine, (b) the shear testing machine.

\subsection{Factors and Level of Factors in Experiments}

By referring to the relevant studies, the factors of the experiments are identified. There are five factors of the strengths of the gold wire bonding, that use five factors to determine the effect of factors to create a regression model of the process. The factors include the gold bonding pressure (bond force), the gold bonding time (bond time), the ultrasonic energy used (USG current), the current released through the EFO to melt the gold wire (EFO current) and the distance between the EFO and the gold wire (EFO gap). The level of factors in the research was based on operation processes and machine 
manuals to determine the appropriate level of each factor used in the experiment so as not to affect the quality of the product, as shown in Table 1.

Table 1: Factors and levels of the experiment

\begin{tabular}{lcccc}
\hline \multirow{2}{*}{ Factors } & \multicolumn{3}{c}{ Level of factors } & Unit \\
\cline { 2 - 4 } & $\mathbf{( - 1 )}$ & $\mathbf{0}$ & $\mathbf{( + 1 )}$ & \\
\hline (A) Bond Force & 70 & 80 & 90 & grams \\
(B) Bond Time & 1 & 2 & 3 & $\mathrm{~ms}$ \\
(C) USG Current & 20 & 35 & 50 & $\mathrm{~mA}$ \\
(D) EFO Current & 40 & 45 & 50 & $\mathrm{~mA}$ \\
(E) EFO Gap & 25 & 30 & 35 & $\mathrm{mils}$ \\
\hline
\end{tabular}

\subsection{Methodology}

In this research, the design of the fractional factorial experiment (FFD) was chosen because it is an experimental design that uses half the number of experiments from the design of a full number of factorial experiments [14,15]. In the case of a study using five factors, the FD experiment used a total of 32 experiments, FFD are used to halve the number of experiments, using only 16, while still maintaining efficient results analysis. There is a good method to create a regression model between the test variable and the response, resulting in a clearer understanding of the main effect and interaction effects between each factor and response.

The fractional factorial design was used to determine five factors that affect the bond shear strength. The experiment was repeated twice with 3 centre point experiments per replication to check the curvature of the regression model using a statistical significance level $\alpha=0.05$ in the experiments. The experiment total is for 38 experiments. The experiments were applied to control other factors that may affect the research response of the three items [16]. The first principle was replication, with two repeated experiments performed; the error of the experiment was calculated and randomized to avoid factors not chosen for analysis [17]. The second was randomization, where the Minitab was used to randomize the trial order to prevent errors. The third was blocking, where all other factors were controlled factors so as not to affect the response of the experiment. The controlled factors included experimenter control, tension, and test experimenter control, which were the same for every experiment; the same machine was used throughout and the gold wire bonding material came from the same lot of material throughout the experimental process. Based on the fractional factorial analysis, results can obtain the regression model to predict bond shear strength over the experimental region. This regression model of the bond shear strength is Eq. 1.

$$
y_{1}=\beta_{0}+\beta_{1} x_{1}+\beta_{2} x_{2}+\beta_{3} x_{3}+\beta_{4} x_{4}+\beta_{5} x_{5}
$$

where $x_{1}, x_{2}, x_{3}, x_{4}$, and $x_{5}$ are the factors of the experiment that represent (A), (B), (C), (D), and (E). $\beta^{\prime} s$ coefficients can be obtained from the effect estimates. $\beta_{0}$ is the average effect of all responses in the 38 experiments.

Residual analysis of the fractional factorial test results for the bond shear strength was a preliminary examination, with the results obtained from the actual experiment shown to be consistent. Three parts were considered: the requirements that the residues must have a normal distribution and, in considering the normal distribution of the residuals, the normal 
probability plot and the histogram were further considered. The final test of the residuals of the trial versus the prediction value (versus fits) was considered to be the residual from the trial order (versus order) $[18,19]$.

\section{RESULTS}

The results obtained from a fractional factorial experiment with 38 trials are shown in Table 2 as the ball shear strengths are recorded.

Table 2: The fractional factorial result of bond shear strength

\begin{tabular}{|c|c|c|c|c|c|c|c|c|c|}
\hline \multicolumn{9}{|c|}{ Experiment parameter } & \multirow{2}{*}{$\begin{array}{c}\text { Ball } \\
\text { shear } \\
\text { strength }\end{array}$} \\
\hline $\begin{array}{c}\text { Std } \\
\text { Order }\end{array}$ & $\begin{array}{c}\text { Run } \\
\text { Order }\end{array}$ & $\begin{array}{c}\text { Center } \\
\text { Pt }\end{array}$ & Blocks & $\begin{array}{c}\text { Ball } \\
\text { Force }\end{array}$ & $\begin{array}{c}\text { Ball } \\
\text { Time }\end{array}$ & $\begin{array}{c}\text { USG } \\
\text { Current }\end{array}$ & $\begin{array}{c}\text { EFO } \\
\text { Current }\end{array}$ & $\begin{array}{l}\text { EFO } \\
\text { Gap } \\
\end{array}$ & \\
\hline 18 & 1 & 1 & 1 & 90 & 1 & 20 & 40 & 25 & 55.23 \\
\hline 5 & 2 & 1 & 1 & 70 & 1 & 50 & 40 & 25 & 51.55 \\
\hline 9 & 3 & 1 & 1 & 70 & 1 & 20 & 50 & 25 & 52.09 \\
\hline 7 & 4 & 1 & 1 & 70 & 3 & 50 & 40 & 35 & 51.51 \\
\hline 19 & 5 & 1 & 1 & 70 & 3 & 20 & 40 & 25 & 52.31 \\
\hline 10 & 6 & 1 & 1 & 90 & 1 & 20 & 50 & 35 & 54.04 \\
\hline 13 & 7 & 1 & 1 & 70 & 1 & 50 & 50 & 35 & 52.27 \\
\hline 8 & 8 & 1 & 1 & 90 & 3 & 50 & 40 & 25 & 53.94 \\
\hline 31 & 9 & 1 & 1 & 70 & 3 & 50 & 50 & 25 & 51.08 \\
\hline 30 & 10 & 1 & 1 & 90 & 1 & 50 & 50 & 25 & 55.35 \\
\hline 15 & 11 & 1 & 1 & 70 & 3 & 50 & 50 & 25 & 51.78 \\
\hline 37 & 12 & 0 & 1 & 80 & 2 & 35 & 45 & 30 & 54.02 \\
\hline 38 & 13 & 0 & 1 & 80 & 2 & 35 & 45 & 30 & 51.64 \\
\hline 6 & 14 & 1 & 1 & 90 & 1 & 50 & 40 & 35 & 54.79 \\
\hline 35 & 15 & 0 & 1 & 80 & 2 & 35 & 45 & 30 & 52.17 \\
\hline 33 & 16 & 0 & 1 & 80 & 2 & 35 & 45 & 30 & 52.95 \\
\hline 23 & 17 & 1 & 1 & 70 & 3 & 50 & 40 & 35 & 53.58 \\
\hline 2 & 18 & 1 & 1 & 90 & 1 & 20 & 40 & 25 & 55.25 \\
\hline 21 & 19 & 1 & 1 & 70 & 1 & 50 & 40 & 25 & 52.80 \\
\hline 22 & 20 & 1 & 1 & 90 & 1 & 50 & 40 & 35 & 54.50 \\
\hline 29 & 21 & 1 & 1 & 70 & 1 & 50 & 50 & 35 & 51.28 \\
\hline 12 & 22 & 1 & 1 & 90 & 3 & 20 & 50 & 25 & 53.69 \\
\hline 32 & 23 & 1 & 1 & 90 & 3 & 50 & 50 & 35 & 52.80 \\
\hline 16 & 24 & 1 & 1 & 90 & 3 & 50 & 50 & 35 & 54.99 \\
\hline 20 & 25 & 1 & 1 & 90 & 3 & 20 & 40 & 35 & 54.69 \\
\hline 1 & 26 & 1 & 1 & 70 & 1 & 20 & 40 & 35 & 51.88 \\
\hline 14 & 27 & 1 & 1 & 90 & 1 & 50 & 50 & 25 & 53.84 \\
\hline 3 & 28 & 1 & 1 & 70 & 3 & 20 & 40 & 25 & 51.80 \\
\hline 17 & 29 & 1 & 1 & 70 & 1 & 20 & 40 & 35 & 52.79 \\
\hline 28 & 30 & 1 & 1 & 90 & 3 & 20 & 50 & 25 & 54.77 \\
\hline 4 & 31 & 1 & 1 & 90 & 3 & 20 & 40 & 35 & 53.49 \\
\hline 34 & 32 & 0 & 1 & 80 & 2 & 35 & 45 & 30 & 52.51 \\
\hline 27 & 33 & 1 & 1 & 70 & 3 & 20 & 50 & 35 & 51.59 \\
\hline 36 & 34 & 0 & 1 & 80 & 2 & 35 & 45 & 30 & 53.39 \\
\hline 11 & 35 & 1 & 1 & 70 & 3 & 20 & 50 & 35 & 50.85 \\
\hline 26 & 36 & 1 & 1 & 90 & 1 & 20 & 50 & 35 & 53.28 \\
\hline 24 & 37 & 1 & 1 & 90 & 3 & 50 & 40 & 25 & 53.02 \\
\hline 25 & 38 & 1 & 1 & 70 & 1 & 20 & 50 & 25 & 52.05 \\
\hline
\end{tabular}

\subsection{Analysis Effect of Factors}

Analysis of the results from the design of the fractional factorial experiments was performed using the Minitab program. The results were found to be a significant factor by a P-value of less than $\alpha=0.05$, which is statistically significant [20]. The factor affected 
the bond shear strength to a statistically significant degree. The bond force is shown in Table 3, which presents the results of the sum of the square of the factors calculated from the fractional factorial test. Figure 5 shows the factors affecting the bond shear strength in the gold wire bonding process via a normal probability plot of the fractional factorial. The results were used to examine the curvature of the regression model, with the bond shear response evaluated by analysis of variance. The P-value was found to be greater than the level of statistical significance according to the linear regression model.

Table 3:. Analysis of variance (ANOVA) of bond shear strength

\begin{tabular}{|c|c|c|c|c|c|c|c|}
\hline Source & DF & $\begin{array}{c}\text { Seq } \\
\text { SS } \\
\end{array}$ & $\begin{array}{c}\text { Adj } \\
\text { SS } \\
\end{array}$ & $\begin{array}{l}\text { Adj } \\
\text { MS }\end{array}$ & $\begin{array}{c}F \\
\text { Value }\end{array}$ & $\begin{array}{c}P \\
\text { Value }\end{array}$ & Significant \\
\hline Main Effects & 5 & 45.039 & 45.039 & 9.008 & 13.740 & 0.000 & Significant \\
\hline Bond Force & 1 & 41.598 & 41.598 & 41.598 & 63.430 & 0.000 & Significant \\
\hline Bond Time & 1 & 1.578 & 1.578 & 1.578 & 2.410 & 0.136 & \\
\hline USG Current & 1 & 0.014 & 0.014 & 0.014 & 0.020 & 0.884 & \\
\hline EFO Current & 1 & 1.697 & 1.697 & 1.697 & 2.590 & 0.123 & \\
\hline EFO Gap & 1 & 0.152 & 0.152 & 0.152 & 0.230 & 0.635 & \\
\hline Two-Way Interactions & 10 & 4.066 & 4.066 & 0.407 & 0.620 & 0.780 & \\
\hline Bond Force*Bond Time & 1 & 0.228 & 0.228 & 0.228 & 0.350 & 0.562 & \\
\hline Bond Force*USG Current & 1 & 0.093 & 0.093 & 0.093 & 0.140 & 0.711 & \\
\hline Bond Force*EFO Current & 1 & 0.299 & 0.299 & 0.299 & 0.460 & 0.507 & \\
\hline Bond Force*EFO Gap & 1 & 0.243 & 0.243 & 0.243 & 0.370 & 0.550 & \\
\hline Bond Time*USG Current & 1 & 0.002 & 0.002 & 0.002 & 0.000 & 0.956 & \\
\hline Bond Time*EFO Current & 1 & 0.101 & 0.101 & 0.101 & 0.150 & 0.699 & \\
\hline Bond Time*EFO Gap & 1 & 0.611 & 0.611 & 0.611 & 0.930 & 0.345 & \\
\hline USG Current*EFO Current & 1 & 0.241 & 0.241 & 0.241 & 0.370 & 0.551 & \\
\hline USG Current*EFO Gap & 1 & 1.507 & 1.507 & 1.507 & 2.300 & 0.144 & \\
\hline EFO Current*EFO Gap & 1 & 0.742 & 0.742 & 0.742 & 1.130 & 0.300 & \\
\hline Curvature & 1 & 0.483 & 0.483 & 0.483 & 0.740 & 0.400 & \\
\hline Residual Error & 21 & 13.771 & 13.771 & 0.656 & & & \\
\hline Pure Error & 21 & 13.771 & 13.771 & 0.656 & & & \\
\hline Total & 37 & 63.360 & & & & & \\
\hline
\end{tabular}

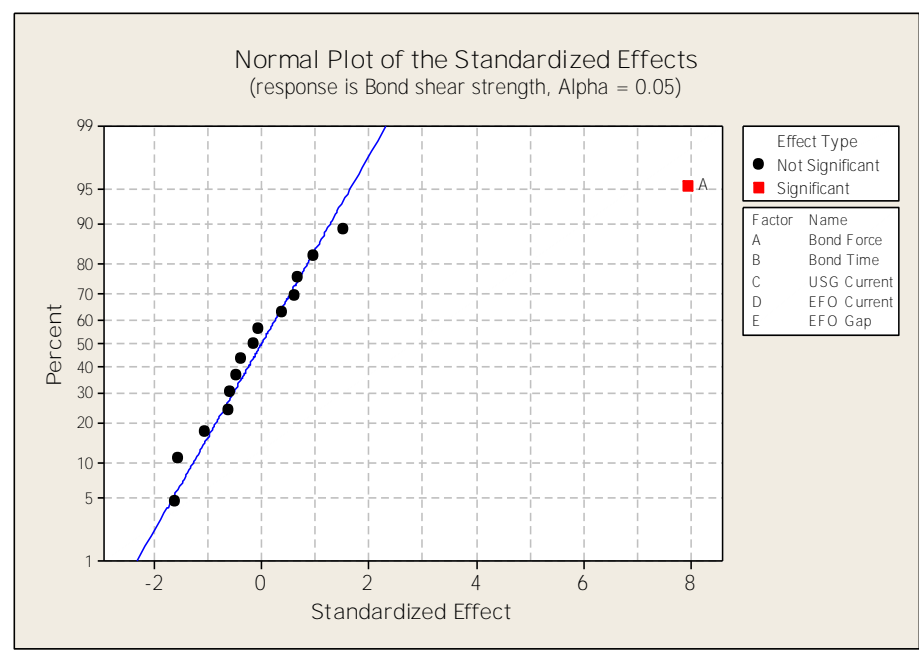

Fig. 5: Normal probability plot of factor that affect to the bond shear strength. 


\subsection{Residual Analysis}

The results of the analysis of the graphs (normal probability plot) and histogram of the experiment showed that the residues of the bond shear strength were normal distribution, with no trend found. For versus fits, there was a random distribution, with no distribution as a trend or pattern occurring. For versus order, the nature of the residual distribution with the trial sequence was random, indicating that the error in the trial sequence was independent, as shown in Fig. 6. The bond shear strength therefore showed no abnormalities or residual tend, showing that the results of the experiment were consistent with the prerequisites of the experiment. Therefore, these experimental results were able to be used.

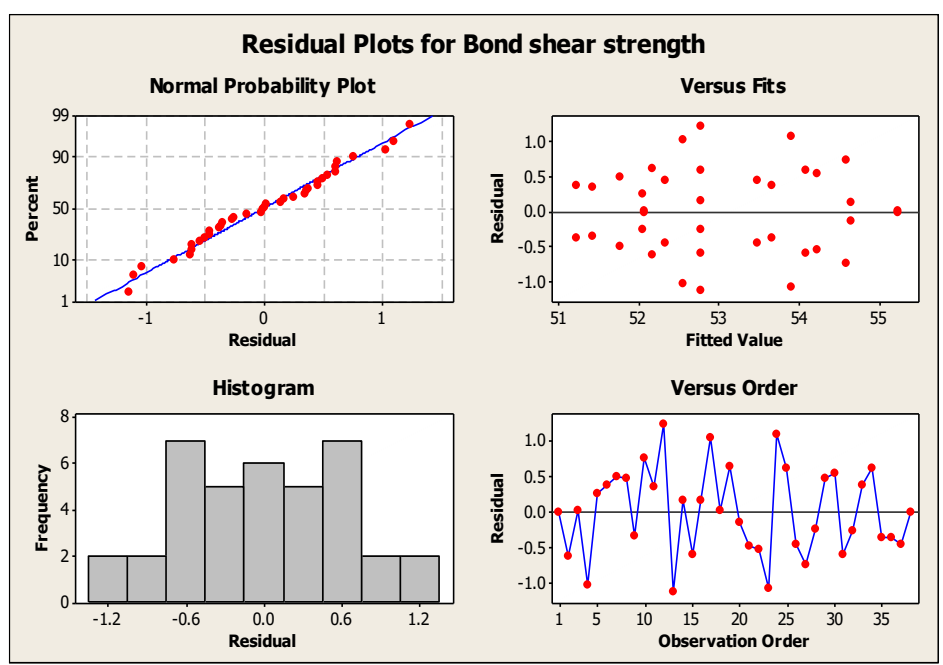

Fig. 6: Residual plot for the fractional factorial test.

\subsection{Regression Model}

The regression model showed that increasing the bond force factor in the gold wire bonding process would increase the bond shear force strength. For other factors, it will have the opposite effect. The production process should be carefully considered when adjustments are made in order to take advantage of the regression model to maximize performance. The regression model was concluded and is described in Eq. 2.

$$
y_{1}=46.64+0.11 x_{1}-0.86 x_{2}-0.11 x_{3}-0.08 x_{4}+0.24 x_{5}
$$

where, $y_{1}$ is the bond shear strength, $x_{1}$ is the bond force, $x_{2}$ is the bond time, $x_{3}$ is the USG current, $x_{4}$ is the EFO current, and $x_{5}$ is the EFO gap.

\section{CONCLUSION}

The statistical method of fractional factorial experiment is a suitable method to determine the effect of large factors in the gold wire bonding process. The experiment was used to determine the effect of five factors by two replications and 3 center point experiments per replication to check the curvature of the regression model. The statistical significance level of the experiments is $\alpha=0.05$, a total of 38 trial experiments were performed. The experiment factors of bond force, bond time, USG current, EFO current, and EFO gap were investigated. The factor found to affect the bond shear strength in the process is the bond force factor of the gold wire bonding process. The regression model 
demonstrated the correlation between coherence that would influence mutual bonding and thereby increase the bond shear strength of the gold wire and increase the strength of the bond force. In these experiments, the expired gold wire bonding capillary is studied. The factors of the shear forces of the welds are different from that of the relevant studies with many factors of the strengths of the welds. For reusing the parts, the bond force is the only factor that significantly affects the increase in the shear force. Therefore, if the manufacturers consider to re-use the expired gold wire bonding capillaries or to increase the useful lives, they can just adjust the bond force of welding to obtain the appropriate shear force.

\section{REFERENCES}

[1] Krajcsák Z. (2019) Implementing open innovation using quality management systems: the role of organizational commitment and customer loyalty. J. of Open Innovation: Technology, Market, and Complexity, 5(4): 90. https://doi.org/10.3390/joitmc5040090

[2] Prabowo R, Singgih ML, Karningsih PD, Widodo E. (2020) New product development from inactive problem perspective in Indonesian SMEs to open innovation. Journal of Open Innovation: Technology, Market, and Complexity., 6(1): 20. https://doi.org/10.3390/joitmc6010020

[3] Phimpha C, Sindhuchao S. (2020) The process of reusing machine part in gold wire bonding process of IC packaging product. The International Academic Conference on Engineering, Technology and Innovations. Bali. Indonesia, pp.13-14.

[4] Hung YH. (2007) Optimal process parameters design for a wire bonding of ultra-thin CSP package based on hybrid methods of artificial intelligence. Microelectronics International, 24(3): 3-10.

[5] Wang, Sun R. (2009) The quality test of wire bonding. Modern Applied Science, 3(12): 50-56.

[6] Bonding W. (2008) The great debate: Copper vs. gold ball bonding. Advanced Packaging, 17(7): 20.

[7] Kim BC, Ha SJ, Yang JK, Lee IC, Kang DS, Han BS, Han YJ. (2017) Process capability optimization of ball bonding using response surface analysis in light emitting diode (LED) wire bonding. Journal of the Korea Academia-Industrial Cooperation Society, 18(4): 175-182.

[8] Zhong ZW. (2009) Fine and ultra-fine pitch wire bonding: challenges and solutions. Microelectronics International, 22(2): 10-18.

[9] Sciammarella FM, Salehi Najafabadi B. (2018) Processing parameter DOE for 316L using directed energy deposition. J. of Manufacturing and Materials Processing, 2(3): 61.

[10] Wu YX, Long ZL, Lei HAN, Zhong J. (2006) Temperature effect in thermosonic wire bonding. Transactions of Nonferrous Metals Society of China, 16(30): 618-622.

[11] Satianrangsarith W, Tirakanogsathit M. (2012) Design of experiments approach for improving wire bonding quality. International Journal of Innovation, Management and Technology, 3(4): 327-331.

[12] Lu D, Wong CP. (2018) Materials for advanced packaging. Springer International Publishing, Switzerland.

[13] Antony J. (2014) Design of experiments for engineers and scientists. Elsevier.

[14] Montgomory DC, Runger GC. (2011) Applied Statistics and Probability for Engineering. John Wiley \& Son Inc, U.S.A.

[15] Gong Y, Song J, Lin S, Yang J, He Y, Tan G. (2020) Design Optimization of Rubber-Basalt Fiber-Modified Concrete Mix Ratios Based on a Response Surface Method. Applied Sciences, 10(19): 6753.

[16] Mayer RM, Montgomery DC. (2011) Response surface methodology: Process and product Optimization using design experiment. John Wiley \& Sons Inc, U.S.A. 
[17] Sabry I, El-Kassas AM, Mourad AHI, Thekkuden DT, Abu Qudeiri J. (2019) Friction stir welding of T-Joints: Experimental and statistical analysis. J. of Manufacturing and Materials Processing, 3(2): 38.

[18] Martin J, De Adana DDR, Asuero AG. (2017) Fitting models to data: residual analysis, a primer. Chapter 7.

[19] Mongomery DC. (2009) Design and analysis of experiment. John Wiley \& Sons Ltd U.S.A.

[20] Mongomery DC. (2009) Statistical Quality Control a Modern introduction. John Wiley \& Sons Ltd U.S.A. 